\title{
CHARACTERISTICS OF BIOLOGICAL MEMBRANES AND COMPUTER MODELING
}

\author{
M. Kojić, ${ }^{1,2,3,4, *}$ I. Vlastelica, ${ }^{5,6}$ B. Stojanović, ${ }^{3,7}$ V. Ranković, ${ }^{3}$ A. Tsuda ${ }^{1}$ \\ ${ }^{1}$ Harvard School of Public Health Harvard University, 677 Huntington Avenue, \\ MA 02115, Boston, USA \\ 2 Department of Nanomedicine and Biomedical Engineering, University of Texas \\ Medical Center at Houston, Houston, USA \\ ${ }^{3}$ Research and Development Center for Bioengineering, Sretenjskog ustava 27, \\ 34000 Kragujevac, Serbia \\ ${ }^{4}$ University of Kragujevac, Kragujevac, Serbia \\ ${ }^{5}$ High School, Čačak, Serbia \\ ${ }^{6}$ Metropolitan University, Belgrade, Serbia \\ ${ }^{7}$ Faculty of Science, University of Kragujevac, Kragujevac, Serbia
}

\begin{abstract}
Mechanical characteristics of biological membranes are very important in functioning of some human organs. A typical example is lung microstructure which represents an alveolated system where the gas exchange occurs at the surface of biological membranes. The overall area of the membrane surface is huge and it significantly changes during inspiration-expiration breathing cycles. The membranes are covered by a surfactant, a surface-active lipoprotein complex, vitally important for the normal lung function.

In this paper we first describe membrane tissue material characteristics obtained by experimental investigations and then briefly summarize computational procedures employed for computer modeling of the biological membrane mechanical response experiencing large deformations over cycling loading. These procedures are implemented to a simple model of biaxial cycling stretching of a biological membrane covered by surfactant, and with elliptical hole and a ring at the hole rim.
\end{abstract}

Keywords: Soft tissue hardening characteristics, hysteresis of tissue and surfactant, computer modeling, finite element method, stress integration.

\section{INTRODUCTION}

We here consider connective biological tissue behavior under mechanical loading. As in the case of engineering materials, the material characteristics are described by appropriate constitutive laws, which are phenomenological in nature, i.e. they are established experimentally. We focus on the soft tissues of the planar (membrane) type which are met in hollow organs such as the lung parenchyma and pleura, stomach, mucous membranes, bladder, uterus, skin, eye, endocardium and pericardium. These tissues usually experience very large strains and stretches (stretches can be of order 2, meaning that a tissue fiber doubles its length) in the normal physiological conditions.

Soft tissues display nonlinear mechanical be havior, i.e. they have nonlinear interdependence between the loadings and deformation, even within the range of the physiological working conditions. These nonlinearities come from shape change and also from the nonlinear constitutive relationships. Also, the time dependent constitutive phenomena, such as creep of material under prolonged loadings, stress relaxation when the strains are held constant over time, or viscous effects under dynamic deformation, are present in physiological processes. In order to have an insight into this character of material response, we here briefly describe the material structure, Kojic et al. 2008 [1].

The main constituents of soft tissues are the extracellular fibrous proteins collagen and elastin. These two constituents usually go together, as in lung parenchyma where their mutual ratio varies with location within the tissue [2], [3]. Mechanical characteristics of the collagen and elastin are very different. Collagen is a relatively inextensible protein. It dominates in tendons and ligaments, as well

${ }^{*}$ Corresponding author: mkojic@hsph.harvard.edu 
as in bone and skin. Individual collagen fibers break at around 2\% strain. However, within tissue these fibers have significant initial slack with no stiffness. In practical applications the collagen fibers can be modeled by a nonlinear constitutive law as shown in Fig. 1 [4].

Elastin is an extensible protein in connective tissues giving them the elastic mechanical behavior. It consists of polypeptide chains which are elongated and sparsely cross-linked and can experience large strains. It can be considered that the constitutive law of elastin bundles is linear even in the domain of large strains. Young's modulus of an elastin fiber is of order $10^{5} \mathrm{~Pa}$. A graphical representation of the elastin constitutive law is given in Fig. 1 for alveolar tissue, together with collagen.

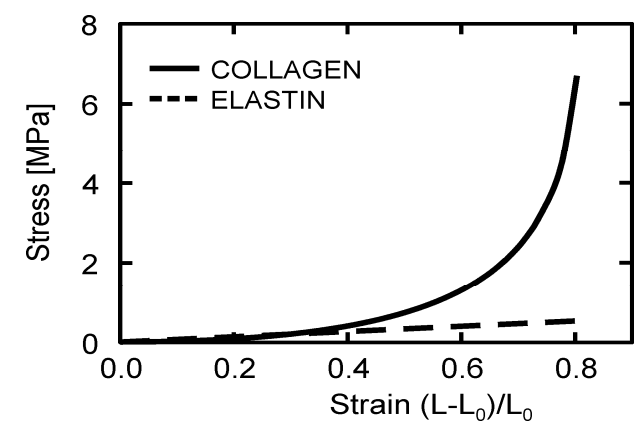

Figure 1. The stress-strain relationships for a network of elastin and collagen fiber bundles (according to Denny and Schroter 2000 [5]; see also references therein).

We further present the main characteristics of biological membranes, together with the typical experiments used to determine these characteristics, and then outline the methods for computer modeling. Further, we implement these methods to model deformation of a biological membrane with a hole, covered with surfactant and with a biological ring at the hole rim; this example is typical and can serve as a model for application in real physiological conditi- ons, as in studying gas exchange in lungs. Finally, some concluding remarks are given in the last section of the paper.

\section{MECHANICAL CHARACTERISTICS}

The main material characteristics of biological tissues are shown here together with the basic experiments. We presented some typical experimental results for isotropic and orthotropic tissue characteristics and the corresponding material models, including models which describe the hysteretic and viscoleastic behavior of tissue.

Uniaxial Test and Uniaxial Model. As for engineering materials, the uniaxial test is the basic mechanical test for characterization of biological tissue. If a strip of a tissue, dissect from a membrane, is stretched quasi-statically, a typical stress-strain relationship shown in Fig. $2 b$ is obtained. It can be seen that the material has a hardening behavior, i.e. the stress nonlinearly increases with strain and that the tissue becomes very stiff at large strains. Also, tissue can display certain hysteretic behavior, as will be shown below.

The tissue material model for uniaxial loading is mathematically defined as dependence of the stress on strain, or, as commonly used, through dependence of the stress $\sigma$ on stretch $\lambda$, i. e. $\sigma=\sigma(\lambda)$

Biaxial Test and Biaxial Model. For the membrane response under general loading conditions, the uniaxial constitutive law is not sufficient. Constitutive laws appropriate for these general conditions are obtained by biaxial tests: a membrane squared strip is stretched in two orthogonal directions, as schematically shown in Fig. 3 a.

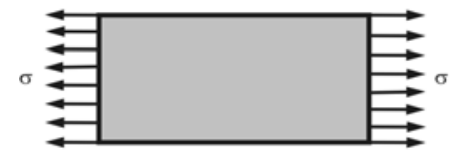

a)

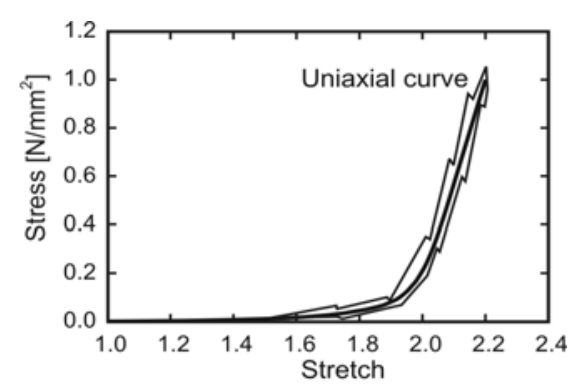

b)

Figure 2. Uniaxial constitutive law for tissue. a) Schematic of uniaxial loading of material element; b) Stress-strain relationship of a strip cut from alveolar tissue (according to Fukaya et al., 1968 [6]). The tissue has a small hysteresis when unloaded. The loading and uloading curves are not smooth because stress relaxations and stress recovery were allowed during the experiment. Idealized constitutive relationship $\sigma=\sigma(\lambda)$ is shown by the solid line as the 
a)

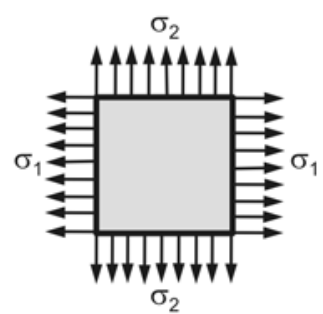

c)

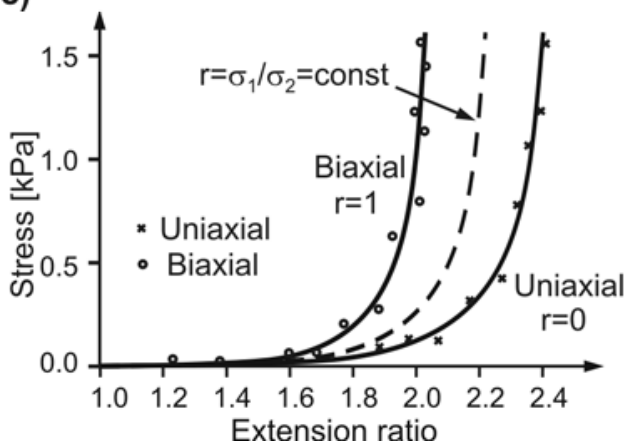

b)

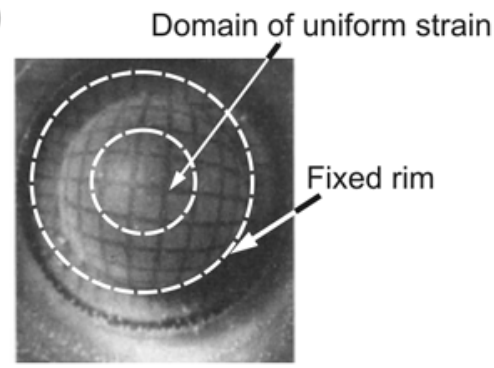

d)

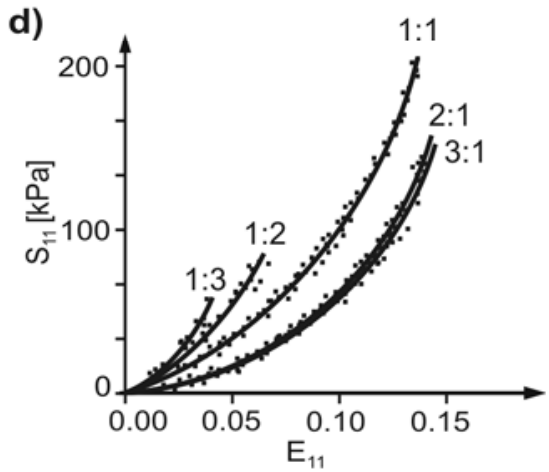

Figure 3. Biaxial stress-strain relationships. a) Schematic of biaxial test; b) Experimental procedure for biaxial testing of isotropic membrane according to Hidebrandt et al. (1969) [7]: circular sample is fixed around the rim and subjected to pressure which produces biaxial stress-strain state (stresses and strains in all directions are the same in the central region); c) Data for uniaxial and biaxial loading and fitted curves for cat mesentery according to [7]; d) Test results and fitted curves for in-plane loading of bovine pericardium under several constant ratios of Green-Lagrange strain $E_{11}$ (preferred fiber direction) and $E_{22}$ (orthogonal to direction of $E_{11}$ ) - stress is the second Piola-Kirchhoff stress (according to Sacks 2000 [8])

When a tissue can be considered isotropic, the loadings in two directions are used to be the same (here called biaxial conditions). This loading can be achieved if a circular sample is fixed along the rim and loading by pressure. Then, in the central region the stress-strain state is the same in all directions [7]. Uniaxial and biaxial experimental data for cat mesentery are shown in Fig. 3b. If the material is loaded by keeping the ratio of the smaller stress $\sigma_{2}$ to the larger stress $\sigma_{1}, r=\sigma_{2} / \sigma_{1}=$ const, a curve lying between the uniaxial and biaxial curves is obtained. Hence, the stretch at a material point is defined by the ratio of the stresses $r$. The model can be described by family of curves

$$
\sigma=\left.\sigma(\lambda)\right|_{r=\text { const }}, \quad r=\sigma_{2} / \sigma_{1}, \quad \sigma_{2} \leq \sigma_{1}
$$

In this biaxial model, the two boundary curves corresponding to experimental findings are the uniaxial curve $\left(\sigma_{2}=0, r=0\right)$ and biaxial curve ( $\left.\sigma_{2}=\sigma_{1}, r=1\right)$ are used, while the other curves are obtained by linear interpolation between these two experimental curves.

Hysteretic Model. It was found experimentally that the connective tissue has hysteretic behavior when subjected to cyclic loading, which is pa- rticularly significant when muscle cells are present (Sasaki and Hoppin 1979 [9]). The experimentally recorded dependence between the tensional force and the material strip length is shown in Fig. 4a. The constitutive law for the hysteretic tissue model is shown in Fig. 4b and is mathematically specified by two relationships:

$\sigma_{\ell}=\sigma_{\ell}(\lambda)$ and $\sigma_{u}=\sigma_{u}(\lambda)$

where the first one corresponds to the loading part within the cycle, with increase of stretch, while the second is the unloading.

Viscoelastic Models. As mentioned above, the biological material can have a viscous character, i.e. the response depends on the rate of deformation. We here specify one of the viscoelastic models, the fiberfiber kinetics model (Mijailovic 1991 [10], Mijailovic et al. 1993, 1994 [11], [12]). The connective tissue is modeled by a system of fibers within an elastic medium (Fig. 5a, top panel). When the tissue deforms the force transfers among fibers and relative sliding among fibers occur generating internal frictional force $T(x, t)=[\operatorname{sign} v(x, t)] \mu p(x, t)+b_{w} v(x, t)$ where $T(x, t)$ is the force per unit length, $v(x, t)$ is the relative velocity at a point $x$ along the fiber, 
$p(x, t)$ is the compressive stress between the fibers; and $\mu$ and $b_{w}$ are the Coulomb and viscous friction coefficients. Due to assumption of symmetry of geometry and loading, one half of the force is transferred to the other fiber through the traction which is generated in the region of sliding (Fig. 5a). In the case of Coulomb friction only, the traction is constant within the sliding region (Fig.5a, bottom panel). The Coulomb friction contributes to the history dependent deformation of tissue, while the viscous friction generates the response corresponding to relaxation. The differential equations of force balance can be integrated and the hysteretic tissue response can be obtained, which is in agreement with experimental ob-

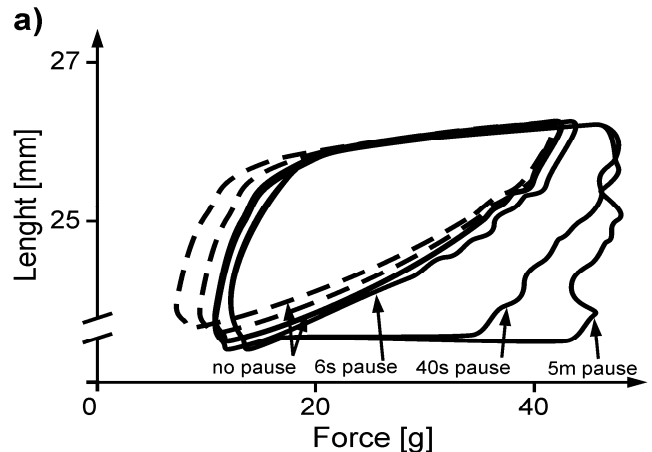

servations (Fig. 5b,c; see references given in the figure caption).

Models of Surfactant Covering Tissue. As mentioned above, biological membranes within organs are covered by surfactant. The surfactant plays important role not only in biophysical processes, but even in biomechanical response of membranes due to action of surface tension of surfactant. This is true in particular for lung microstructure (e.g. Wilson 1982 [15], Ingenito et al. 1999 [16], Bachofen and Schurch 2001 [17]). Here, the description of mechanical behavior of surfactant refers first of all to lung surfactant.

b)

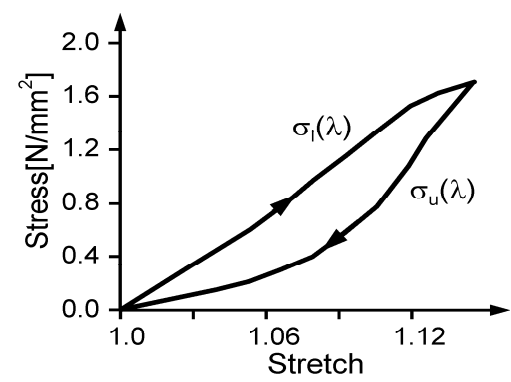

Figure 4. Hysteretic response of smooth muscle tissue. a) Experimental results on airway dog trachealis muscle strips (according to Sasaki and Hoppin 1979 [9]) (lg=0.00981 N); b) Constitutive model for tissue histeresis expressed as the stress-stretch relationship: $\sigma_{\ell}(\lambda)$ is the loading curve and $\sigma_{u}(\lambda)$ is the unloading curve for one cycle). Note that the axes in the graph b) are used as it is usual in engineering practice, opposite from figure a).

a)
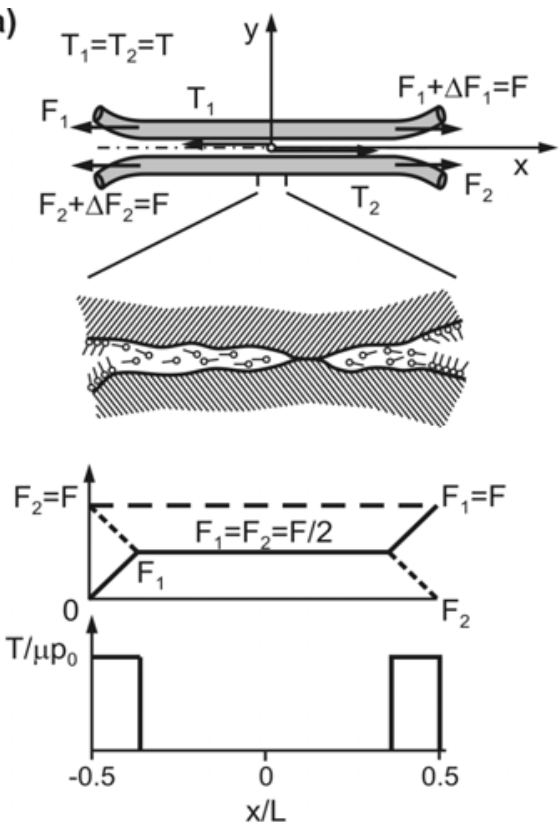

b)

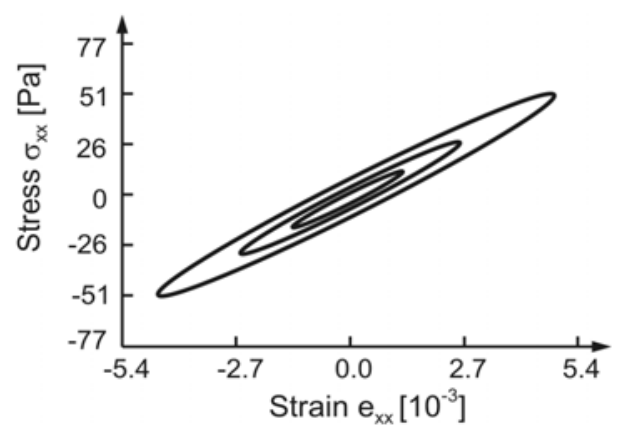

c)

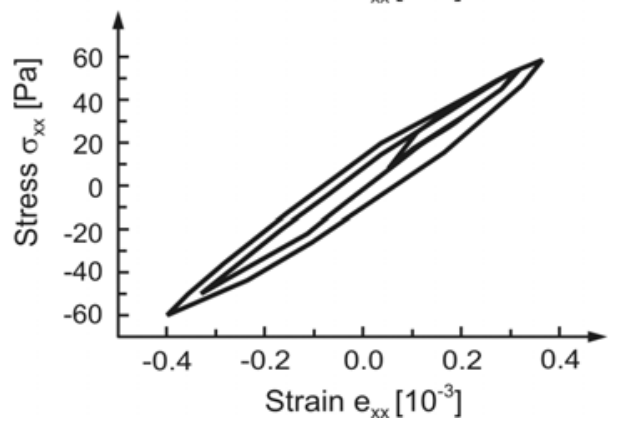

Figure 5. Fiber-fiber kinetics model of connective tissue. a) Schematics of the model, from top-down: extensional force $F$ transferred among fibers as forces $F_{1}$ and $F_{2}$, enlarged contact between fibers, distribution of force within fibers, distribution of contact traction $T$; b) Experimental stress-strain hysteretic loops when the tissue is loaded cyclically (according to [10]); c) Computed hysteresis (according to [11], [12]; Kojic et al. 1998, 2003 [13], [14]) 


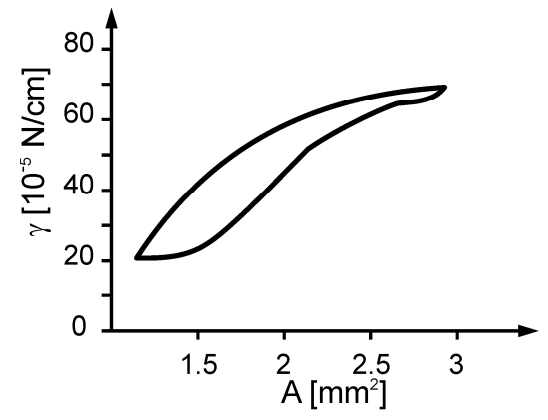

a)

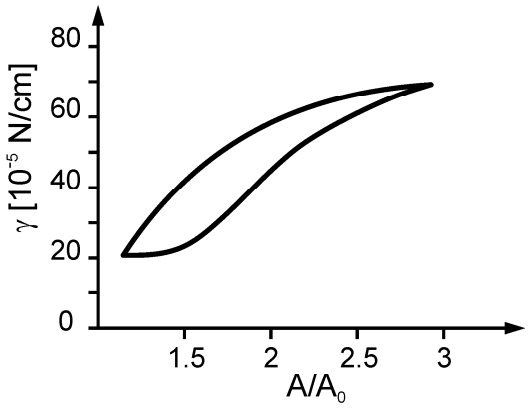

b)

Figure 6. Hysteretic characteristic of surface tension. a) Experimentally determined dependence of surface tension on the surfactant area A (according to Ingenito et al. 1999 [16]); b) Idealized dependence of surface tension on area ratio ( $A_{0}$ is the initial area)

It can be seen from Fig. 6 that surface tension depends on the surfactant area and has a hysteretic characteristic. This hysteresis plays important role in lung functioning and gas exchange deep in the lung. In the mathematical description of surface tension $\gamma$ we will use the relation

$$
\gamma=\gamma\left(A / A_{0}\right)
$$

where $A / A_{0}$ is the ratio of the current area and the initial area of the surfactant (at a given point of the surfactant surface).

We next outline the nonlinear finite element computational procedure for modeling biological tissue response and briefly present stress calculation for the biaxial model and surfactant.

\section{COMPUTER MODELING}

The most commonly used numerical method for modeling physical fields, which includes displacement field during biological tissue deformation, is the finite element method (Kojic et al. 1998 [18], Kojic and Bathe 2005 [19], Kojic et al. 2008 [1]). In the case of nonlinear problems, an incremental-iterative procedure is employed, and the equilibrium equation of a finite element can be written as (following [1])

$$
\left({ }^{n+1} \mathbf{K}_{L}+{ }^{n+1} \mathbf{K}_{N L}\right)_{\text {tissue }}^{(i-1)} \Delta \mathbf{U}^{(i)}={ }^{n+1} \mathbf{F}^{\text {ext }}-{ }^{n+1} \mathbf{F}_{\text {tissue }}^{\text {int }(i-1)}
$$

which corresponds to the step ' $n$ ' and iteration ' $i$ '. Here, $\left({ }^{n+1} \mathbf{K}_{L}\right)_{\text {tissue }}$ and ${ }^{n+1} \mathbf{K}_{N L}$ are the linear and geometrically nonlinear stiffness matrices; ${ }^{n+1} \mathbf{F}^{\text {ext }}$ and ${ }^{n+1} \mathbf{F}_{\text {tissue }}^{\text {int }(i-1)}$ are the external forces acting to the element, which include the action of the surrounding finite elements, and internal forces due to stresses within the tissue; $\Delta \mathbf{U}^{(i)}$ is the vector of increments of nodal displacements; and the left upper index ' $n+1$ ' denotes end of the incremental step. The matrix ${ }^{n+1} \mathbf{K}_{N L}$ is the same as for any solid, while the matrix
${ }^{n+1} \mathbf{K}_{L}$ and the internal force vector contain the material tissue characteristics. They are

$$
\begin{gathered}
\left({ }^{n+1} \mathbf{K}_{L}\right)_{\text {tissue }}^{(i-1)}=\int_{V}{ }_{V}^{n+1}\left(\mathbf{B}_{L}^{T} \mathbf{C}_{\text {tissue }} \mathbf{B}_{L}\right)^{(i-1)} d V, \\
{ }^{n+1} \mathbf{F}_{\text {tissue }}^{\text {int }(i-1)}=\int_{V}{ }^{n+1} \mathbf{B}_{L}^{T}{ }^{T+1} \boldsymbol{\sigma}_{\text {tissue }}^{(i-1)} d V
\end{gathered}
$$

where ${ }^{n+1} \mathbf{B}_{L}^{(i-1)}$ the linear strain-displacement matrix; ${ }^{n+1} \mathbf{C}_{\text {tissue }}^{(i-1)}$ is the tangent constitutive matrix for tissue; and ${ }^{n+1} \boldsymbol{\sigma}_{\text {tissue }}^{(i-1)}$ is the stress tensor within tissue (written here in a matrix form). Integration is performed over the last known element volume $V^{(i-1)}$. We will give below some details how the stress ${ }^{n+1} \boldsymbol{\sigma}_{\text {tisse }}^{(i-1)}$ and the matrix ${ }^{n+1} \mathbf{C}_{\text {tissue }}^{(i-1)}$ can be evaluated for the biaxial tissue model.

In the case of membrane analysis, the above general 3-D equations are transformed to the tangential plane and stress calculation is performed in a local membrane coordinate system (see Fig. 8). Details about these transformations are given in [1].

In the case of membrane (shell) and biaxial model, we consider that the stretches ${ }^{n+1} \lambda_{1}$ and ${ }^{n+1} \lambda_{2}$ and the principal directions ${ }^{n+1} \overline{\mathbf{p}}_{1}$ and ${ }^{n+1} \overline{\mathbf{p}}_{2}$ in the tangential plane of the shell element, are known for the end of time step and previous iteration $(i-1)$. If ${ }^{n+1} \lambda_{1}>^{n+1} \lambda_{2}$, then we introduce the stress ratio ${ }^{n+1} r$ as (Kojic et al. 2006 [20], see Fig. 7)

${ }^{n+1} r=\frac{{ }^{n+1} \sigma_{2}}{{ }^{n+1} \sigma_{1}}$

The stress ${ }^{n+1} \sigma_{1}$, corresponding to stretch ${ }^{n+1} \lambda_{1}$, is obtained as a linear interpolation between stresses at uniaxial and biaxial curves ${ }^{n+1} \sigma_{u}$ and ${ }^{n+1} \sigma_{b}$,

${ }^{n+1} \sigma_{1}\left({ }^{n+1} \lambda_{1}\right)=\left(1-{ }^{n+1} r\right){ }^{n+1} \sigma_{u}+{ }^{n+1} r^{n+1} \sigma_{b}$

The relation (9) also follows from a linear interpolation of tangent modulus between the valu- 
es $E_{\lambda u}$ and $E_{\lambda b}$ on uniaxial and biaxial curves to obtain ${ }^{n+1} E_{\lambda}$ on the curve with ${ }^{n+1} r$,

${ }^{n+1} E_{\lambda}=\left(1-{ }^{n+1} r\right){ }^{n+1} E_{\lambda u}+{ }^{n+1} r{ }^{n+1} E_{\lambda b}$

and the stress increment

$\Delta \sigma_{1}={ }^{t+\Delta t} E_{\lambda} \Delta \lambda_{1}$

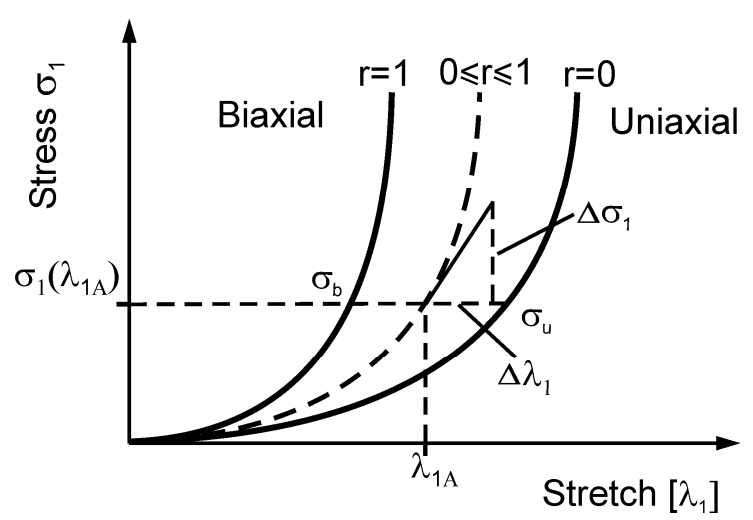

Figure 7. Stress-stretch relations for uniaxial ( $r=0)$, biaxial ( $r=1)$ and $r=\sigma_{2} / \sigma_{1}=$ const conditions. The stress $\sigma_{1 A}$ for stretch $\lambda_{1 A}$ is linearly interpolated from the stresses $\sigma_{b}$ and $\sigma_{u}$ on the biaxial and uniaxial curves.

The tangent modulus $E_{\lambda}$ is $E_{\lambda}=\Delta \sigma_{1} / \Delta \lambda_{1}$.

Using the secant modulus corresponding to the calculated stress ${ }^{n+1} \sigma_{1}$ and the plane stress conditions, the stress ${ }^{n+1} \sigma_{2}$ is obtained as

${ }^{n+1} \sigma_{2}={ }^{n+1} \sigma_{1} \frac{v^{n+1} e_{1}+{ }^{n+1} e_{2}}{{ }^{n+1} e_{1}+v^{n+1} e_{2}}$

where ${ }^{n+1} e_{1}$ and ${ }^{n+1} e_{2}$ are the total strains measured from the undeformed configuration. We here use the

a)

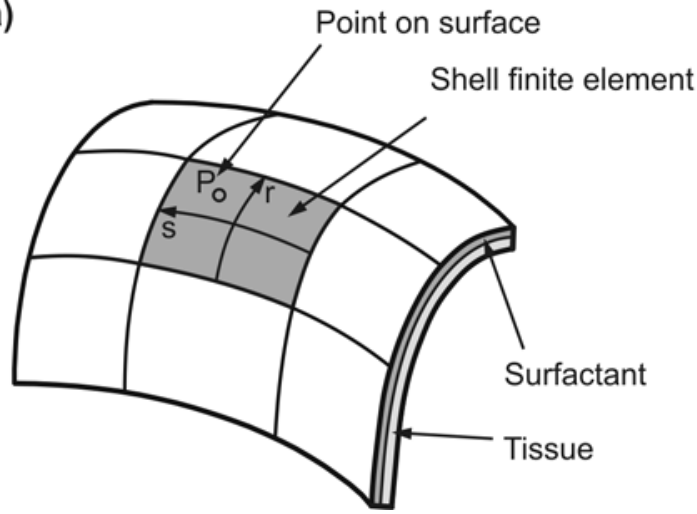

logarithmic strains, hence ${ }^{n+1} e_{1}=\ln \left({ }^{n+1} \lambda_{1}\right)$ and ${ }^{n+1} e_{2}=\ln \left({ }^{n+1} \lambda_{2}\right)$.

The constitutive matrix for the in-plane principal directions can be derived as

$$
\overline{\mathbf{C}}={ }^{n+1} \lambda_{1}{ }^{n+1} E_{\lambda} \frac{1-{ }^{n+1} r v}{1-v^{2}}\left[\begin{array}{ccc}
1 & v & 0 \\
v & 1 & 0 \\
0 & 0 & \frac{1-v}{2}
\end{array}\right]
$$

Consider now a membrane covered by surfactant as schematically shown in Fig. 8. We assume that there is no slip between the surfactant layer and tissue therefore, the change of the surfactant area during membrane deformation is the same as the change of the membrane area. The surface tension $\gamma[\mathrm{N} / \mathrm{m}]$ is a function of the ratio of the current surfactant area $A$ and the initial area, $A /^{\circ} A$, see Fig. 6. At a membrane point on the surface $P$, the surface tension can be expressed in the form

$\gamma=\gamma\left(\frac{d A}{d^{0} A}\right)=\gamma\left(\frac{\operatorname{det} \mathbf{J}}{\operatorname{det}^{0} \mathbf{J}}\right)$

where $\mathbf{J}$ and ${ }^{0} \mathbf{J}$ are Jacobians of transformation between Cartesian coordinate system and natural coordinate system $r$, s of the membrane finite element, corresponding to the current and undeformed configurations, respectively.

Figure 8. Biological membrane covered with surfactant and modeled by shell finite elements. The surfactant deforms as the shell surface. a) Geometry of the membrane and surfactant; b) Stress in tissue and surfactant (in the first principal strain direction)

For a current membrane deformation, the surface tension can be determined using the experimentally determined dependence $\gamma\left(A /{ }^{0} A\right)$. In the computational procedure we employ a scaling concept, where the experimental curve is scaled in order to meet the deformation conditions along the membrane surface (see schematics in Fig. 9). Details about this scaling are given in [1] and [20]. 
Surface tension has the same action on the tissue in all directions within the surface (see Fig. 8). We evaluate the stress ${ }^{n+1} \sigma_{(\gamma)}$ equivalent to the surface tension ${ }^{n+1} \gamma$, as

$$
{ }^{n+1} \sigma_{(\gamma)}=\frac{{ }^{n+1} \gamma}{{ }^{n+1} \delta}
$$

where ${ }^{n+1} \delta$ is the membrane thickness at integration point. This stress is superimposed to the tissue stresses when evaluating nodal forces of a finite element. Also, a tangent constitutive matrix due to surfactant can be computed in a consistent manner [1, 20].

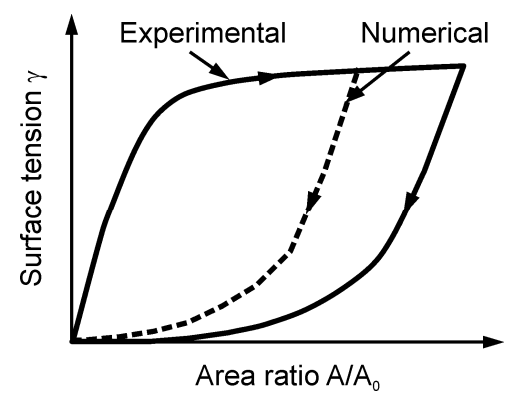

Figure 9. Dependence of surface tension $\gamma$ on the surfactant area ratio $A /{ }^{0} A$ for the surfactant covering alveolar lung miscrostucture during inspiration-expiration cycles (Wilson 1982 [15]). Dashed curve (Numerical) is obtained by a scaling procedure. Note that the surface tension is much higher during inspiration

Finally, we notify how the hysteretic behavior of tissue fibers is incorporated into membrane modeling. It is assumed that direction of fibers is known for the current membrane configuration and that the hysteretic stress-stretch relationship is given (see Fig. 4). Then, we implement a scaling procedure to follow history of deformation for each fiber point, as schematically shown in Fig. 10 (see [1] and [15] for details).

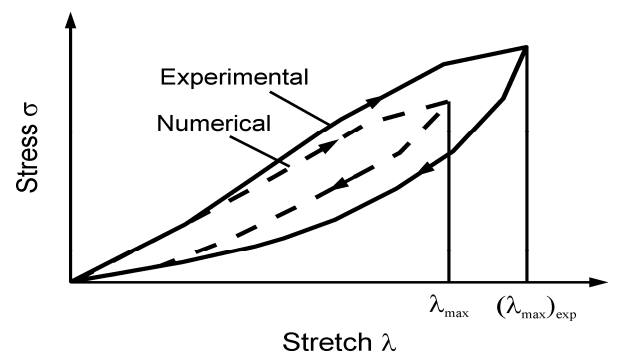

Figure 10. Experimental and numerical stress-stretch loops

\section{EXAMPLE: CYCLIC BIAXIAL STRETCH OF BIOLOGICAL MEM- BRANE WITH A HOLE, COVERED BY SURFACTANT AND WITH A RING AT THE HOLE RIM}

Here we calculate mechanical response of a biological membrane with an elliptical hole when subjected to biaxial cyclic loading (Fig. 11). The membrane is covered on both sides by surfactant and has a biological ring at the hole rim. It is assumed that the membrane material behaves according to the above described biaxial model, while the surfactant and ring have hysteretic properties. The solutions are obtained using a FE discretization and the stress integration presented in the previous section.

Geometry of the membrane is shown in Fig. 11a. The solution is obtained by using the prescribed displacement at the external boundary, by increasing the displacement $u_{\text {ext }}$ incrementally ( 20 equal steps to the maximum displacement of $0.1 \mathrm{~mm}$ ), followed by a decrease $u_{\text {ext }}$ to zero. Note that, since the material models do not depend on the rate of displacements, the current deformation is determined only by the value of $\mathrm{u}_{\mathrm{ext}}$ (and the loading regime - loading or unloading); solution accuracy, of course, depends on the step size. One quarter of the membrane is modeled due to symmetry of geometry and loading; the FE model and boundary conditions are shown in Fig. 11b. Material characteristics of the tissue, surfactant and ring are given in Fig. 11c.

Solutions for displacements of points $\mathrm{D}$ and $\mathrm{E}$ (see Fig 11b) in terms of the external displacement are shown in Figs. 11d and 11e, respectively. It can be seen that the displacements have hysteretic character during a loading cycle, caused by hysteresis of surfactant and ring. The hysteretic curves in case of action of surfactant are above those when surfactant is not present; this is due to the fact that surfactant is acting on the membrane as external loading with the increase of the membrane deformation. 
a)

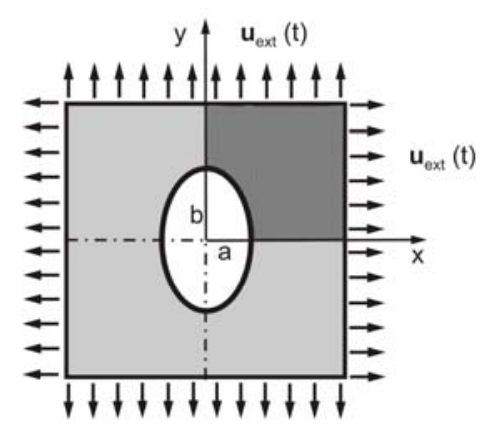

b)

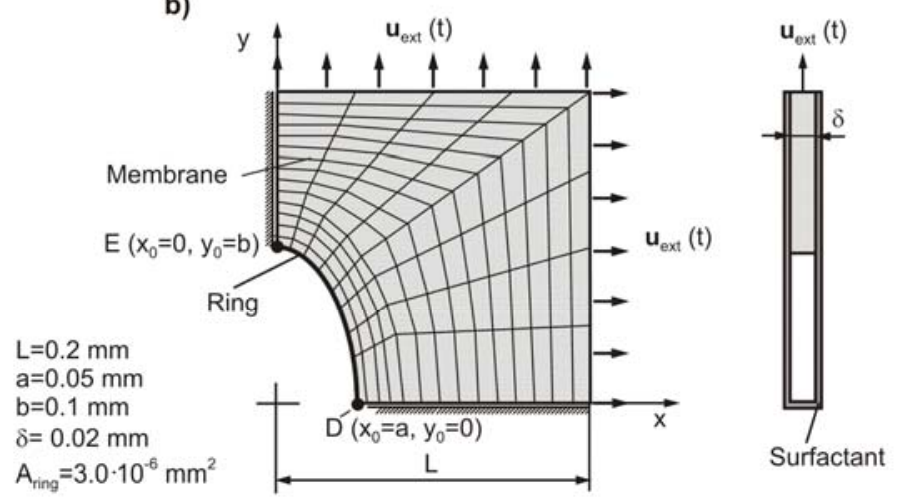

c)
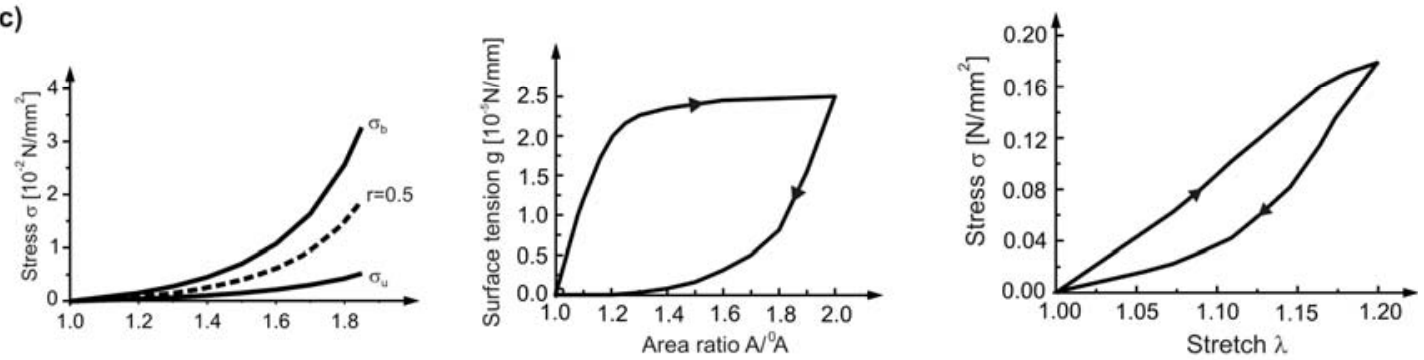

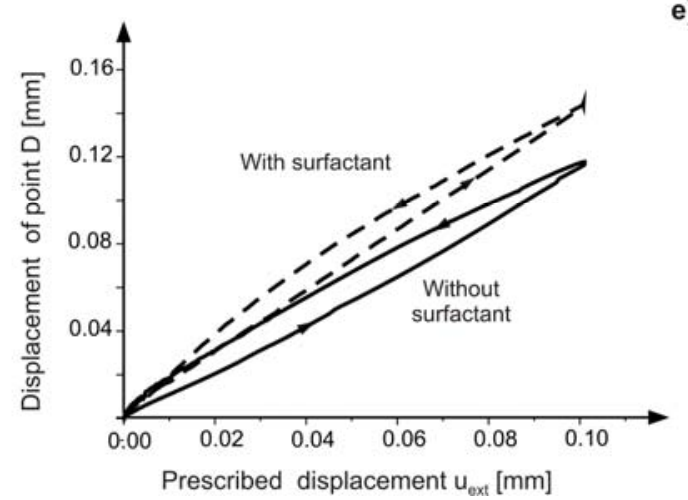

e)

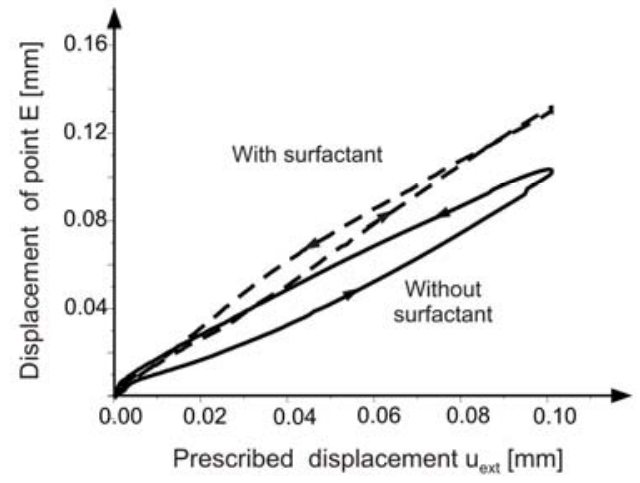

Figure 11. Biaxial stretching of biological membrane with elliptical hole covered by surfactant and with a ring at the hole rim. a) Geometry of the membrane ( $A_{\text {ring }}$ is the cross-sectional area of the ring), with prescribed displacements at the external boundary; b) Finite element model with boundary conditions; c) Material characteristics (from left to right) of membrane tissue, surfactant and ring; d), e) Displacements of points $D$ and $E$ in terms of prescribed cyclic displacement at the external boundary.

\section{CONCLUDING REMARKS}

Physiological function of organs depends, among other factors, on tissue material characteristics. These characteristics are commonly determined by experimental investigations and are mathematically expressed as constitutive laws. Typical examples of the constitutive laws shown in the paper illustrate material behavior, which includes hardening and hysteretic properties.

In studying the phenomena relevant for various biophysical processes, the role of computer mo- deling is rapidly increasing. We have summarized our computational procedures developed for membrane tissue modeling. These procedures are applied to modeling response of a biological membrane with a hole, covered by surfactant and with a ring having hysteretic characteristics. The calculated membrane deformation has a hysteretic behavior. The overall hysteresis of the membrane is produced by hystereses of surfactant and ring material. The presented approach in computer modeling can be implemented to analyze various phenomena of interest in lung mechanics or in physiology of other organs structu- 
rally composed of biological membranes (e.g. Kojic et al. [22]).

\section{ACKNOWLEDGMENTS}

This study was supported by several grants: NIH Grants HL054885, HL070542 and HL074022; NASA NNJ06HE06A and State of Texas, Emerging Technology Fund; Ministry of Science and Technological Development of Serbia (Grant OI-144028); and City of Kragujevac.

\section{REFERENCES}

[1] M. Kojić, N. Filipović, B. Stojanović, N. Kojić, Computer Modeling in Bioengineering - Theoretical Background, Examples and Software, J. Wiley and Sons, 2008.

[2] C. G. Lee, F. G. Jr Hoppin (1972). Lung elasticity. In: Biomechanics-Its Foundations and Objectives. edited by Fung YC, Perrone N, Anliker M, 317-335, Prentice-Hall, Inc., Englewood Cliffs, N.J.

[3] E.H. Oldmixon, F. G. Jr Hoppin (1989). Distribution of elastin and collagen in canine lung alveolar parenchyma, J. Appl. Physiol., 67(5), 19411949.

[4] R. Kowe, R. C. Schroter, F. L. Matthews, D. Hitchings (1986). Analysis of elastic and surface tension effects in the lung alveolus using finite element methods. J. Biomechanics 19 (7): 541-549.

[5] E. Denny, R. C. Schroter (2000). Viscolelastic behavior of a lung alveolar duct model, J. Biomech. Engrg. Trans. ASME, 122, 143-151.

[6] H. Fukaya, C. J. Martin, A. C. Young, S. Katsura (1968). Mechanical properties of alveolar walls, J. Appl. Physiol., 25(6), 689-695.

[7] J. Hildebrandt, H. Fukaya, C.J. Martin (1969). Stress-strain relations of tissue sheets undergoing uniform two-dimensional stretch, J. Appl. Physiol., 27(5), 758-762.

[8] M. S. Sacks (2000). Biaxial mechanical evaluation of planar biological materials, J. Elasticity, 61, 194-246.

[9] H. Sasaki, F. G. Jr Hoppin (1979). Hysteresis of contracted airway smooth muscle, J. Appl. Physiol: Respirat. Environ. Excercise Physiol., 47(6), 1251-1262.

[10] S. M. Mijailovic (1991). Elasticity and Energy Dissipation in Lung Connective Tissue. $\mathrm{Ph}$. D. Thesis, MIT, Cambridge, MA.
[11] S. M. Mijailovic, D. Stamenovic, J. J. Fredberg (1993). Toward a kinetic theory of connective tissue micromechanics, J. Appl. Physiol., 74(2), 665-681.

[12] S. M. Mijailovic, D. Stamenovic, R. Brown, D.E. Leith, J.J. Fredberg (1994). Dynamic moduli of rabit lung tissue and pigeon ligamentum propatagiale undergoing uniaxial cyclic loading, $\mathrm{J}$. Appl. Physiol., 76(2), 773-782.

[13] M. Kojic, S. Mijailovic, N. Zdravkovic (1998). A numerical algorithm for stress integration of a fiber-fiber kinetics model with Coulomb friction for connective tissue, Comp. Mech., 21(2), 189-198.

[14] M. Kojic, N. Zdravkovic, S Mijailovic (2003). A numerical stress calculation procedure for a fiber-fiber kinetics model with Coulomb and viscous friction of connective tissue, Comp. Mech., 30, 185-195.

[15] T. A. Wilson (1982) Surface tension-surface area curves calculated from pressure-volume loops, J. Appl. Physiol: Respirat. Environ. Excercise Physiol., 53(6), 1512-1520.

[16] E. P. Ingenito, L. Mark, J. Morris, F. F. Espinosa, R.D. Kamm, M. Johnson (1999). Biophysical chracterization and modeling of lung surfactant components, J. Appl. Physiol., 86(5), 17021714.

[17] H. P. Bachofen, H. Schurch (2001). Alveolar surface forces and lung architecture, Comp. Biochem. Physiol. Part A, 129, 183-193.

[18] Miloš Kojić and Klaus-Jürgen Bathe, Inelastic Analysis of Solids and Structures, BerlinHeidelberg, 2005.

[19] M. Kojić, R. Slavković, M. Živković, N. Grujović, (1998), Finite Element Method I - Linear analysis, Mechanical Engineering Faculty, University of Kragujevac, Serbia.

[20] M. Kojic, I. Vlastelica, B. Stojanovic, V. Rankovic, A. Tsuda (2006). Stress integration procedures for a biaxial isotropic material model of biological membranes and for hysteretic models of muscle fibers and surfactant, Int. J. Num. Meth. Engrg., 68, 893-909.

[21] J. Gil, H. Bachofen, P. Gehr and E.R. Weibel. Alveolar volume-surface area relation in air-and saline-filled lungs fixed by vascular perfusion. J. Appl. Physiol: Respirat. Environ. Excercise Physiol. 47(5): 990-1001, 1979.

[22] M. Kojic, J. P. Butler, I. Vlastelica, B. Stojanovic, V. Rankovic, A. Tsuda, Geometric hysteresis of alveolated ductal architecture, to be submitted. 


\section{$\sin 3$ \\ КАРАКТЕРИСТИКЕ БИОЛОШКИХ МЕМБРАНА И КОМПЈУТЕРСКО МОДЕЛОВАњЕ}

Сажетак: Механичке карактеристике биолошких мембрана веома су важне у функционисању неких људских органа. Типичан примјер је микроструктура плућа, која представља алвеоларни систем гдје се размјена гаса дешава на површини биолошких мембрана. Укупно подручје површине мембране је огромно а значајно се смањује у току удисаја-издисаја у циклусима дисања. Мембране су покривене сурфактантом, површински активним липопротеинским комплексом, који је од виталног значаја за нормално функционисање плућа.

У раду прво описујемо материјалне карактеристике мембранског ткива, добијене експерименталним истраживањем, а затим укратко сумирамо компјутерске процедуре примијењене у комјутерском моделовању механичког одговора биолошке мембране која доживљава велике деформације у току цикличног оптерећења. Ове процедуре су примијењене на једноставни модел двоосовинског растезања биолошке мембране покривене сурфактантом, са елиптичним отвором и прстеном на цијелом рубу отвора.

Кључне ријечи: карактеристике стврдњавања меког ткива, хистереза ткива и сурфактант, компјутерско моделовање, метод финитног елемента, интеграција стреса. 